\title{
The Effect of Hand Hygiene Promotion in a University Hospital in China
}

\section{Li-Li Xiang ${ }^{1}$, Duo-Shuang Xie ${ }^{2,3^{*}}$, Rui Li ${ }^{2}$, Xiang-Yun Fu², Hui-Fang Wang ${ }^{2}$,Qiao Hu² ${ }^{2}$,in-Qing Luo ${ }^{2}$, Lei Wang ${ }^{4}$, Rui-Ping Lai ${ }^{2}$ and Han-Lin Liao ${ }^{2}$}

${ }^{1}$ Physical examination center, Taihe Hospital, Hubei University of Medicine, Shiyan, Hubei, China

${ }^{2}$ Department of Infection Control, Taihe Hospital, Hubei University of Medicine, Shiyan, Hubei, China

${ }^{3}$ Center of Health Administration and Development studies, Hubei University of Medicine, Shiyan, Hubei, China

${ }^{4}$ Hospital Administration Office, Taihe Hospital, Hubei University of Medicine, Shiyan, Hubei, China

"Corresponding author: Duo-Shuang Xie, Department of Infection Control, Taihe Hospital, Hubei University of Medicine, No 32 Renmin Road, Shiyan, Hubei 430030 , PR China, Tel: +86 719 8801606, Fax: +86 719 8801379; E-mail: xieds8@163.com

Received date: September 05, 2014; Accepted date: October 14, 2014; Published date: October 17, 2014

Copyright: () 2014 Xiang LL, et al. This is an open-access article distributed under the terms of the Creative Commons Attribution License, which permits unrestricted use, distribution, and reproduction in any medium, provided the original author and source are credited.

\begin{abstract}
Objective: Implementing a multimodal campaign could be resulted in a sustained increase in hand hygiene ( $\mathrm{HH})$ compliance rates. However, most studies of $\mathrm{HH}$ campaign have been conducted in the developed countries. This study was aimed to evaluate the effectiveness of hand hygiene campaign in a university hospital in China.

Methods: During the period of the $\mathrm{HH}$ campaign, the WHO hand hygiene improvement strategy was implemented to improve hand hygiene compliance. We collected and evaluated the effect of hand hygiene campaign by the questionnaire of WHO hand hygiene observation, consumption of alcohol-based hand rub (AHR), liquid soap and gloves, and the quality of $\mathrm{HH}$ by adenosine triphosphate (ATP) test.
\end{abstract}

Results: Of the 4,177 opportunities of hand hygiene evaluated, the $\mathrm{HH}$ compliance improved significantly from $24.2 \%$ to $41.0 \%$ after the intervention. Health care workers in the ICU showed higher hand hygiene compliance compared with those in other departments. In general, Nurses' hand hygiene compliance was higher than those of physicians and surgeons. The consumption of AHR and the ATP pass rate increased after the intervention.

Conclusion: Through the intervention, medical staff hand hygiene compliance was greatly improved from $24.2 \%$ to $41.0 \%$. The WHO Hand Hygiene Strategy was also effective in hospital of China.

Keywords: Hand hygiene campaign; Compliance; Healthcare associated infection; China

\section{Introduction}

Healthcare-associated infection (HAI) accounts for one of the most common complications in hospitalized patients, and is a major contributor to prolonged hospital stay and increased healthcare costs $[1,2]$.

In recent years, improving patient safety has received more and more attention, and the first goal of the World Health Organization (WHO) World Alliance for Patient Safety is "the Clean Care is Safer Care" [3]. Hand hygiene ( $\mathrm{HH})$, i.e. washing hand with soap and water, or disinfecting hands with alcohol-based hand rub (AHR), is considered to be a simple, but most effective method of preventing HAI and cutting off the spread of antimicrobial-resistant pathogens [4-6]. In 2009, the WHO has issued hand hygiene guidelines for health care workers (HCW) [2].

The efficiency of $\mathrm{HH}$ is well-known, however, numerous studies have shown that without any intervention the rate of $\mathrm{HH}$ compliance remained low $[7,8]$.

It's been reported that implementing a multimodal campaign could resulted in a sustained increase in $\mathrm{HH}$ compliance rates. However, most studies of $\mathrm{HH}$ campaign have been conducted in the developed countries [5,8-11]. In 2009, the Ministry of Health of China (MOH) issued a national health industry standard Hand Hygiene Norms for Medical Staff [12]. From then on, HH campaigns were conducted in a few hospitals in China. In Taihe Hospital, Hand Hygiene Campaign was conducted with those effective tools. This study was undertaken to evaluate $\mathrm{HH}$ behavior of HCW before and after the $\mathrm{HH}$ campaign in the hospital, and to add the experience of the WHO Hand Hygiene Strategy conducted in the developing countries.

\section{Materials and Methods}

\section{Setting}

The study was performed from January 2012 to April 2013 in Taihe Hospital. Taihe Hospital, also named the Affiliated Hospital of Hubei University of Medicine, is a tertiary hospital, founded in 1965 and located in the City of Shiyan, Hubei Province of China. There are 2900 beds for adults and children, and 1067 nurses and 707 physicians or surgeons in the hospital totally, with 99000 admissions in 2012. The hospital included a general intensive care unit (ICU) and all medical specialties being represented. Due to the limitation of research labor power, we selected the following departments to conduct the study: internal medicine (comprising respiratory, gastroenterology, cardiology, endocrinology, hepatology, nephrology, hematology, and neurology), departments of surgery (comprising general surgery, cardiac and cerebral surgery, neurosurgery, orthopedics, urology, plastic and burn, oncology, obstetrics and gynecology), pediatrics, 
Page 2 of 6

ICUs, and others (comprising Chinese traditional medicine, dentistry, ENT [ears, nose and throat] medicine, ophthalmology and dermatology). This study was reviewed and approved by the Ethics and Health Research Review Committee of Taihe Hospital, Hubei University of Medicine.

\section{Design}

The baseline $\mathrm{HH}$ compliance rate of HCW was established from January to August 2012. After the first observation period, comprehensive intervention was implemented in September and October, 2012 by the infection control team. We conducted this study using the WHO hand hygiene improvement strategy.

The strategy consists of 5 core elements [13]:

(1) System change, including access to AHR at the point of patient care and to liquid soap, towels, and a safe, continuous water supply. AHR bottles were installed along the passageway and the foot of every patient bed in an attempt to enable easy access by HCW to the HH products.

(2) Training and educating HCWs: All the HCW in the hospital received the theoretical and practical training which was delivered by the director or the trained nurses of the infection control team, and we tried some innovative training methods, such as hand hygiene slogan and promotional items solicitation and hand hygiene knowledge contest.

(3) Monitoring practices and providing feedback on performance. Data of HH compliance and consumption of AHR, liquid soap and gloves were provided monthly for each ward by our study team.

(4) Posting visual reminders in the workplace.

(5) Creating a safety climate within the institution with the active, visible participation of both individual HCW and senior hospital managers. Before the intervention, each wards must paid for these $\mathrm{HH}$ products, including AHR, liquid soap, gloves, and hand tissue. After the intervention, these items were provided by the hospital, and the consumption of related $\mathrm{HH}$ material didn't add any financial burden to each ward.

\section{Data collection}

For the evaluation of these opportunities, a special assessment sheet was provided. The following parameters were recorded: (1) the name and type of the wards, (2) the type of opportunity for $\mathrm{HH}$, and (3) the type of action performed (washing hands, AHR, glove, no action). The observations was performed respectively before and after the intervention at least 50 opportunities in each wards to ensure a standardized manner of observation. Compliance rates were then calculated as percentages, using direct observation by trained observers via a standardized assessment sheet designed by WHO. These opportunities were evaluated according to the standardized WHO definitions and divided it into 5 groups [14]: (1) before contact to the patient, (2) before aseptic practice, (3) after contact to potentially infectious agents, (4) after contact to the patient, and (5) after contact to patients' environment. Results of $\mathrm{HH}$ compliance rates were calculated separately for different category of departments, and different medical professionals.

In addition, consumption of AHR, liquid soap, and glove were recorded and evaluated monthly by our study team.

\section{Adenosine triphosphate monitering}

Except for hand hygiene improvement strategy, adenosine triphosphate (ATP) was used to monitor and improve the quality of hand hygiene in this study. In each wards, HCW were selected at random and asked to wash their hands with liquid soap and running water. When the hands were completely dry, the investigator rubbed the swab against the tips of each finger, in between each finger and then in an S-shape along the palm of one hand. Then the swab was placed in the monitor, and in no time the results recorded automatically. An explanation of the score was given and the improvement in technique to achieve cleaner hands was discussed with HCW in the spot.

The ATP monitoring system was System SURE Plus, produced by Hygiena International, Watford, UK, 2011. The score $<30$ was considered pass according the manufacturer's recommendation. During the observations of hand hygiene compliance at each department, the 2-3 HCW who washed his/her hands with flowing water were chosen to be tested by ATP detection.

\section{Statistical analyses}

Statistical analysis was performed using descriptive statistics such as frequency, percentage of $\mathrm{HH}$ compliance and the 95\% confidence interval (CI). Statistical analysis was performed by SAS, version 8.2.,and Bartlett's Chi-squared test was used to evaluate the inequality of percentages, and $\mathrm{P}$ values $<0.05$ (two-tailed) were considered statistically significant.

\section{Results}

\section{HH compliance rates}

Overall, 4177 opportunities events requiring $\mathrm{HH}$ were observed during all phases of the study, with 1914 opportunities before the intervention and 2263 after. There were more than $700 \mathrm{HCW}$ attended the hand hygiene slogan and promotional items solicitation, and hand hygiene knowledge contest. During the period of $\mathrm{HH}$ campaign, more than $423 \mathrm{HH}$ slogans and $40 \mathrm{HH}$ promotional items were created personally by HCW of Taihe Hospital.

Compliance rates of investigated groups were summarized and presented in Table 1. From January to August 2012 before the intervention, the $\mathrm{HH}$ compliance was $24.2 \%$. After the intervention a significant improvement of $\mathrm{HH}$ compliance was assessed in the period from September 2012 to April 2013 (from overall 24.2\% to 41.0\%, $\mathrm{P}<$. 0000).

There was significant difference in $\mathrm{HH}$ compliance among departments and professionals both before and after the intervention. Before the intervention, the highest rate of $\mathrm{HH}$ compliance was observed in ICU $(30.4 \%)$, followed by the internal medicine units $(27.3 \%)$ and the pediatric units $(24.0 \%)$. After the intervention, the high rate were noticed in ICU (47.2\%), then the surgical wards (46.7\%) and others departments (42.3\%). Compared with physicians and surgeons, nurses were noticed with the higher rate of $\mathrm{HH}$ compliance both before (30.9\%) and after (44.8\%) the intervention.

According to the 5 groups of opportunities defined by WHO, $\mathrm{HH}$ was performed more frequently after body fluid exposure risk. 
Citation: $\quad$ Xiang LL, Xie DS, Li R, Fu XY, Wang HF. et al. (2014) The Effect of Hand Hygiene Promotion in a University Hospital in China. J Nurs

Page 3 of 6

\begin{tabular}{|c|c|c|c|c|c|c|c|}
\hline \multirow[t]{2}{*}{ Variable } & \multicolumn{3}{|l|}{ Baseline } & \multicolumn{3}{|l|}{ Follow-up } & \multirow{3}{*}{$\begin{array}{l}P \\
\\
0.00\end{array}$} \\
\hline & $\begin{array}{l}\text { No. of hand } \\
\text { hygiene } \\
\text { actions }\end{array}$ & $\begin{array}{l}\text { No. }(\%) \text { of hand } \\
\text { hygiene opportunities }\end{array}$ & $\begin{array}{l}\text { Compliance, } \\
(95 \% \mathrm{Cl})\end{array}$ & $\begin{array}{l}\text { No. of hand } \\
\text { hygiene } \\
\text { actions }\end{array}$ & $\begin{array}{l}\text { No. }(\%) \text { of hand } \\
\text { hygiene opportunities }\end{array}$ & $\begin{array}{l}\text { Compliance, } \quad \% \\
(95 \% \mathrm{Cl})\end{array}$ & \\
\hline Overall & 464 & 1914 & $24.2(22.3-26.2)$ & 927 & 2263 & $41.0(38.9-43.0)$ & \\
\hline \multicolumn{8}{|l|}{ Departments } \\
\hline Internal medicine & 132 & 483 & 27.3(23.4-31.3) & 173 & 552 & $31.3(27.5-35.2)$ & 0.16 \\
\hline Surgical & 86 & 459 & 18.7(15.2-22.3) & 398 & 852 & $46.7(43.4-50.1)$ & 0.00 \\
\hline ICU & 75 & 247 & $30.4(24.6-36.1)$ & 137 & 290 & $47.2(41.5-53.0)$ & 0.00 \\
\hline Pediatric & 82 & 342 & $24.0(19.5-28.5)$ & 117 & 328 & $35.7(30.5-40.9)$ & 0.00 \\
\hline Others departments & 89 & 383 & $23.2(19.0-27.5)$ & 102 & 241 & $42.3(36.1-48.6)$ & 0.00 \\
\hline \multicolumn{8}{|l|}{ Professional category } \\
\hline Nurse & 311 & 1006 & $30.9(28.1-33.8)$ & 601 & 1342 & $44.8(42.1-47.4)$ & 0.00 \\
\hline Physician & 63 & 324 & $19.4(15.1-23.8)$ & 120 & 350 & $34.3(29.3-39.3)$ & 0.00 \\
\hline Surgeon & 90 & 584 & $15.4(12.5-18.3)$ & 206 & 571 & $36.1(32.1-40.0)$ & 0.00 \\
\hline \multicolumn{8}{|l|}{ Indications } \\
\hline $\begin{array}{l}\text { Before patient } \\
\text { contact }\end{array}$ & 131 & 579 & $22.6(19.2-26.0)$ & 153 & 437 & $35.0(30.5-39.5)$ & 0.00 \\
\hline $\begin{array}{l}\text { Before aseptic } \\
\text { procedure }\end{array}$ & 108 & 365 & $29.6(24.9-34.3)$ & 186 & 376 & $49.5(44.4-54.5)$ & 0.00 \\
\hline $\begin{array}{l}\text { After body fluid } \\
\text { exposure risk }\end{array}$ & 87 & 157 & $55.4(47.6-63.2)$ & 130 & 190 & $68.4(61.8-75.0)$ & 0.01 \\
\hline After patient contact & 76 & 422 & $18.0(14.3-21.7)$ & 352 & 916 & $38.4(35.3-41.6)$ & 0.00 \\
\hline $\begin{array}{l}\text { After contact to } \\
\text { patients environment }\end{array}$ & 62 & 391 & $15.9(12.2-19.5)$ & 106 & 344 & $30.8(25.9-35.7)$ & 0.00 \\
\hline
\end{tabular}

Table 1: Compliance rates of investigated subgroups in a university hospital in China.

Others departments, Departments of Chinese traditional medicine, dentistry, ENT [ears, nose and throat] medicine, ophthalmology, and dermatology.

The most extensive improvement of $\mathrm{HH}$ compliance was recognized on our surgical ward (18.7\%), which ended up reaching the higher $\mathrm{HH}$ compliance rates of all ( $46.7 \%$ after the intervention). Lowest improvement after the intervention (4.0\%) was evaluated on internal medicine wards ( $31.3 \%$ after the intervention).

\section{AHR, liquid soap and glove consumption}

The overall use of AHR, liquid soap and glove by HCW in different departments increased significantly. Before the Clean Hands Campaign, the highest AHR consumption rates were recorded in ICU (median: $11.8 \mathrm{~mL}$ per patient-day), followed by the surgical wards $(3.0$ $\mathrm{mL})$ and the pediatric wards $(1.4 \mathrm{~mL})$. Meanwhile, the highest liquid soap consumption was in ICU (median: $25.3 \mathrm{~mL}$ per patient-day), followed by the surgical wards $(8.8 \mathrm{~mL})$, and the Internal medicine wards $(4.3 \mathrm{~mL})$. The median AHR, liquid soap and glove of all participating wards is presented in Table 2 and Figure 1.

\begin{tabular}{|c|c|c|c|c|c|}
\hline Departments & \multicolumn{2}{|l|}{ Period } & $\mathrm{AH}$ & Liquid & Glov \\
\hline \multirow[t]{4}{*}{ Internal medicine } & \multirow[t]{2}{*}{$\begin{array}{l}\text { Before } \\
\text { intervention }\end{array}$} & $\begin{array}{l}\text { Jan.- } \\
2012\end{array}$ & 0.2 & 2.7 & 0.3 \\
\hline & & $\begin{array}{l}\text { May-Aug., } \\
2012\end{array}$ & 0.6 & 5.7 & 0.3 \\
\hline & \multirow[t]{2}{*}{ After intervention } & $\begin{array}{l}\text { Sep.-Dec., } \\
2012\end{array}$ & 4.0 & 8.9 & 0.3 \\
\hline & & $\begin{array}{l}\text { Jan.- } \\
2013\end{array} \quad$ Apr., & 4.1 & 8.3 & 0.4 \\
\hline \multirow[t]{4}{*}{ Surgical } & \multirow[t]{2}{*}{$\begin{array}{l}\text { Before } \\
\text { intervention }\end{array}$} & $\begin{array}{l}\text { Jan.- } \\
2012\end{array} \quad$ Apr., & 2.8 & 7.1 & 0.2 \\
\hline & & $\begin{array}{l}\text { May-Aug., } \\
2012\end{array}$ & 3.1 & 10.3 & 0.2 \\
\hline & \multirow[t]{2}{*}{ After intervention } & $\begin{array}{l}\text { Sep.-Dec., } \\
2012\end{array}$ & 5.0 & 16.5 & 0.2 \\
\hline & & $\begin{array}{l}\text { Jan.- } \quad \text { Apr., } \\
2013\end{array}$ & 3.9 & 12.9 & 0.2 \\
\hline
\end{tabular}


Page 4 of 6

\begin{tabular}{|c|c|c|c|c|c|}
\hline \multirow[t]{4}{*}{ ICU } & \multirow[t]{2}{*}{$\begin{array}{l}\text { Before } \\
\text { intervention }\end{array}$} & $\begin{array}{l}\text { Jan.- } \\
2012\end{array}$ Apr., & $\begin{array}{l}45 . \\
2\end{array}$ & 26.5 & 1.6 \\
\hline & & $\begin{array}{l}\text { May-Aug., } \\
2012\end{array}$ & $\begin{array}{l}48 . \\
9\end{array}$ & 23.8 & 2.6 \\
\hline & \multirow[t]{2}{*}{ After intervention } & $\begin{array}{l}\text { Sep.-Dec., } \\
2012\end{array}$ & $\begin{array}{l}79 . \\
8\end{array}$ & 31.4 & 2.6 \\
\hline & & $\begin{array}{l}\text { Jan.- } \\
2013\end{array}$ & $\begin{array}{l}63 . \\
2\end{array}$ & 34.1 & 2.9 \\
\hline \multirow[t]{4}{*}{ Pediatric } & \multirow[t]{2}{*}{$\begin{array}{l}\text { Before } \\
\text { intervention }\end{array}$} & $\begin{array}{l}\text { Jan.- } \\
2012\end{array}$ & 1.2 & 1.7 & 0.2 \\
\hline & & $\begin{array}{l}\text { May-Aug., } \\
2012\end{array}$ & 1.5 & 2.6 & 0.1 \\
\hline & \multirow[t]{2}{*}{ After intervention } & $\begin{array}{l}\text { Sep.-Dec., } \\
2012\end{array}$ & 4.5 & 4.3 & 0.2 \\
\hline & & $\begin{array}{l}\text { Jan.- } \\
2013\end{array}$ & 4.0 & 6.7 & 0.1 \\
\hline \multirow[t]{4}{*}{$\begin{array}{l}\text { Others } \\
\text { departments }\end{array}$} & \multirow[t]{2}{*}{$\begin{array}{l}\text { Before } \\
\text { intervention }\end{array}$} & $\begin{array}{l}\text { Jan.- } \\
2012\end{array}$ & 0.3 & 3.3 & 0.3 \\
\hline & & $\begin{array}{l}\text { May-Aug., } \\
2012\end{array}$ & 0.6 & 3.5 & 0.3 \\
\hline & \multirow[t]{2}{*}{ After intervention } & $\begin{array}{l}\text { Sep.-Dec., } \\
2012\end{array}$ & 2.1 & 5.0 & 0.3 \\
\hline & & $\begin{array}{l}\text { Jan.- } \quad \text { Apr., } \\
2013\end{array}$ & 1.8 & 6.0 & 0.3 \\
\hline
\end{tabular}

Table 2: AHR, liquid soap and gloves consumption of investigated subgroups in a university hospital in China.

NOTE: Others departments, Departments of Chinese traditional medicine, dentistry, ENT [ears, nose and throat] medicine, ophthalmology, and dermatology. Values are median; milliliter per patient-day for AHR and liquid soap, pair per patient-day for glove.

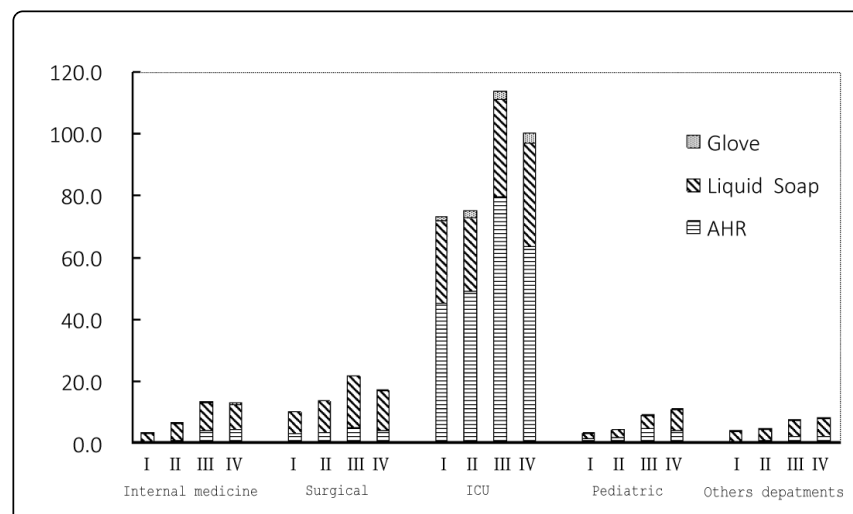

Figure 1: AHR, liquid soap and gloves consumption of investigated subgroups in a university hospital in China.

NOTE. AHR, alcohol-based hand rub. Others departmens, Departments of Chinese traditional medicine, dentistry, ENT [ears, nose and throat] medicine, ophthalmology, and dermatology.,Jan.Apr. 2012;, May-Aug., 2012; , Sep.-Dec., 2012; , Jan.- Apr., 2013.

\section{ATP results}

In the ATP test, 333 subjects were testedand the pass rate was $86.79 \%$. The mean pass rate prior to the $\mathrm{HH}$ intervention was $79.75 \%$ (126of $158 \mathrm{HCW}$ had scores <30). After the intervention, the rate increased to $93.14 \%$ (163of 175 HCW had scores $<30)(\mathrm{P}<0.001)$.

\section{Discussion}

$\mathrm{HH}$ was widely accepted as an effective measure to reduce HAI in healthcare settings. Implementation of infection control in the developing countries was complex and must take into account many factors, including costs, lack of knowledge, deficient infrastructure, and cultural issues [15].

To our knowledge, few data about $\mathrm{HH}$ compliance rates in China hospitals have been previously reported in international journals. In comparison with data from other institutions $[9,10]$, compliance rates at Taihe Hospital seem to be rather low before the intervention, but enhancement was obvious after the intervention. In this hospital, enhancement was still possible and very much required.

In the health system of China, state financing only counted to about $25-30 \%$ of total costs [16]. Medical institutions must try to save costs. Before the intervention, materials of hand hygiene always were inadequate in this hospital. Beginning from September 2012, the hospital provided adequate AHR, liquid soap and hand towel for all the wards. The financial policy that each ward needn't pay for these materials encouraged the $\mathrm{HH}$ compliance. The WHO guidelines for hand hygiene reflected evidence that accessibility to AHR near patient locations is key to assist HCW to practice hand hygiene [2].

It is reported that training in $\mathrm{HH}$ should be a key element for a successful education, especially in academic professions. Intensive training and education are essential to improve compliance rates and to achieve sustained effect. In this study, we added some games such as hand hygiene slogan and promotional items solicitation, and hand hygiene knowledge contest. The use of gaming technology to provide education and assessment not only improved technique, but also increased compliance with the Five Moments for Hand Hygiene across the hospital [10].

Consistent with the previous reports $[17,18]$, compliance with hand hygiene varied across indications, medical specialties, and HCW categories. Like other studies [9,18-21], compliance improved across all medical specialties and all professional categories after the intervention. As demonstrated by this study, the intervention had an effective influence on the overall $\mathrm{HH}$ compliance rate among the medical staff.

The professional status of a HCW was an influencing factor of $\mathrm{HH}$ compliance in several studies $[7,22,23]$. A systematic review published in 2010 showed that the median hand hygiene compliance was $40 \%$, and among physicians, in intensive care units and prior to patient contact the hand hygiene compliance was lower [24].

Similarly, a difference in compliance between the professional groups in our hospital became apparent during the Campaign. All groups, including nurses, physicians, and surgeons improved with respect to $\mathrm{HH}$ compliance, but this effect was much more evident in the surgeons' group. The present study showed that most of the missed $\mathrm{HH}$ actions were after touching the patient environment and after/ before patient contact, meanwhile, the highest rate of $\mathrm{HH}$ compliance indication was after body fluid exposure risk. This finding is in 
Page 5 of 6

agreement with many published studies $[25,26]$. The reason might be that HCW scared more for their own protection rather than their patients.

The compliance rates of $\mathrm{HH}$ among the medical staff of the 5 departments were different both before and after the intervention. In ICU, severely immuno-compromised patients are treated. This fact seems to enhance HCWs HH compliance. In this study, its compliance rate of $\mathrm{HH}$ was the highest one. This observation is concordant with other studies $[17,18]$.

After the intervention, the surgical units showed the best improvement of $\mathrm{HH}$ in our institution with compliance rates ranging from $18.7 \%$ to $46.7 \%$. A reason for this observation may be that the baseline compliance was rather low.

AHR and liquid soap consumption can reflect the real $\mathrm{HH}$ compliance. In China, there isn't a national reference data of AHR consumption. After the intervention, the AHR consumption in the study was $63.2-79.8 \mathrm{~mL}$ per patient-day in ICU, and 1.8-5.0 mL per patient-dayinnon-ICUs, while in a study conducted in Germany in 2009, in which the median AHR in 543 ICUs was $83 \mathrm{~mL}$ per patientday, and the median AHR in 3339 non-ICUs was $18 \mathrm{~mL} /$ patient-day [27]. The AHR removes microorganisms effectively, requires less time and irritates hands less often than does hand washing with soap or other antiseptic agents and water [28]. In our study, in non-ICUs, the liquid soap consumption was more than AHR. The reason might be the difference of work habit and needs more detailed research to find out.

There are several limitations in our studies. First, our study was conducted using the direct observation method. There are concerns about the methods used for training the observers, the assessment of inter-rater reliability and the potential bias for staff members to change their behavior when they know that they are being observed $[29,30]$. Second, the follow-up period was short and further studies are needed to evaluate the sustainability of the intervention of $\mathrm{HH}$ campaign. Third, the present study was inability to identify the most effective element(s) of the intervention.

Despite these limitations, we consider the observed improvements to be very promising, because compliance was poor at baseline and this multifaceted approach was introduced for the first time in this cultural context. We recognize, however, that further progress needs to be made.

Next, further study is needed to confirm the improvements in the HAI rates and infections due to multidrug-resistant bacteria associated with the improved rate of $\mathrm{HH}$ compliance.

\section{Conclusion}

In this study, we have compared compliance rates before and after the intervention of hand hygiene Campaign in a university hospital in China. In our study we found that $\mathrm{HH}$ campaign is feasible and effective in a healthcare setting in, similar to other countries. Otherwise, the WHO strategy and derived tools are evidence-based and ready-to-use in planning and conducting hand hygiene promotion in healthcare facilities all over the world, including China.

\section{Acknowledgments}

Financial support. This study was no funded.
Potential conflicts of interest- All authors report no conflicts of interest relevant to this article.

\section{References}

1. Burke JP (2003) Infection control - a problem for patient safety. N Engl J Med 348: 651-656.

2. Mathai E, Allegranzi B, Kilpatrick C, Pittet D (2010) Prevention and control of health care-associated infections through improved hand hygiene. Indian J Med Microbiol 28: 100-106.

3. World Health Organization (2013)WHO programmes and activities: First Global Patient Safety Challenge - Clean Care is Safer Care

4. Duckro AN, Blom DW, Lyle EA, Weinstein RA, Hayden MK (2005) Transfer of vancomycin-resistant enterococci via health care worker hands. Arch Intern Med 165: 302-307.

5. Pittet D, Hugonnet S, Harbarth S, Mourouga P, Sauvan V, et al. (2000) Effectiveness of a hospital-wide programme to improve compliance with hand hygiene. Infection Control Programme. Lancet 356: 1307-1312.

6. Pittet D, Allegranzi B, Sax H, Dharan S, Pessoa-Silva CL, et al. (2006) Evidence-based model for hand transmission during patient care and the role of improved practices. Lancet Infect Dis 6: 641-652.

7. Erasmus V, Daha TJ, Brug H, Richardus JH, Behrendt MD, et al. (2010) Systematic review of studies on compliance with hand hygiene guidelines in hospital care. Infect Control Hosp Epidemiol 31: 283-294.

8. Scheithauer S, Oude-Aost J, Heimann K, Haefner H, Schwanz T, et al. (2011) Hand hygiene in pediatric and neonatal intensive care unit patients: daily opportunities and indication- and profession-specific analyses of compliance. Am J Infect Control 39: 732-737.

9. Aboumatar H, Ristaino P, Davis RO, et al. (2012) Infection Prevention Promotion Program Based on the PRECEDE Model: Improving Hand Hygiene Behaviors among Healthcare Personnel. Infect Control Hosp Epidemiol 33: 144-151.

10. Barrera L, Zingg W, Mendez F, Pittet D (2011) Effectiveness of a hand hygiene promotion strategy using alcohol-based handrub in 6 intensive care units in Colombia. Am J Infect Control 39: 633-639.

11. Helder OK, Brug J, Goudoever JB, Looman CWN, Reiss IKM, Kornelisse $\mathrm{RF}(2014)$ Sequential hand hygiene promotion contributes to a reduced nosocomial bloodstream infection rate among very low-birth weight infants: An interrupted time series over a 10-year period. Am J Infect Control 42: 718-22.

12. The Ministry of Health of China. Norm of hand hygiene for health care workers (in Chinese). 2009.

13. Pittet D, Allegranzi B, Storr J (2008) The WHO Clean Care is Safer Care programme: field-testing to enhance sustainability and spread of hand hygiene improvements. J Infect Public Health 1: 4-10.

14. Pittet D, Allegranzi B, Boyce J (2014) For the World Health Organization World Alliance for Patient Safety First Global Patient Safety Challenge Core Group of Experts. The World Health Organization Guidelines on Hand Hygiene in Health Care and Their Consensus Recommendations. Infect Control Hosp Epidemiol 30:611-622.

15. Raka L (2009) Lowbury Lecture 2008: infection control and limited resources--searching for the best solutions. J Hosp Infect 72: 292-298.

16. Liu X, Liu Y, Chen N (2000) The Chinese experience of hospital price regulation. Health Policy Plan 15: 157-163.

17. Mazi W, Senok AC, Al-Kahldy S, Abdullah D (2013) Implementation of the world health organization hand hygiene improvement strategy in critical care units. Antimicrob Resist Infect Control 2: 15.

18. Rosenthal VD, Pawar M, Leblebicioglu H, Navoa-Ng JA, VillamilGḮEmez W, et al. (2013) Impact of the International Nosocomial Infection Control Consortium (INICC) Multidimensional Hand Hygiene Approach over 13 Years in 51 Cities of 19 Limited-Resource Countries from Latin America, Asia, the Middle East, and Europe. Infect Control Hosp Epidemiol 34: 415-423.

19. Salama MF, Jamal WY, Mousa HA, Al-Abdulghani KA, Rotimi VO (2013) The effect of hand hygiene compliance on hospital-acquired 
Citation: $\quad$ Xiang LL, Xie DS, Li R, Fu XY, Wang HF. et al. (2014) The Effect of Hand Hygiene Promotion in a University Hospital in China. J Nurs

Page 6 of 6

infections in an ICU setting in a Kuwaiti teaching hospital. J Infect Public Health 6: 27-34

20. Sahay S, Panja S, Ray S, Rao BK (2010) Diurnal variation in hand hygiene compliance in a tertiary level multidisciplinary intensive care unit. Am J Infect Control 38: 535-539.

21. Scheithauer S, Haefner H, Schwanz T, Schulze-Steinen H, Schiefer J, et al. (2009) Compliance with hand hygiene on surgical, medical, and neurologic intensive care units: direct observation versus calculated disinfectant usage. Am J Infect Control 37: 835-841.

22. Chaberny IF, Möller I, Graf K (2009) Hand hygiene and campaigns. Pneumologie 63: 219-221.

23. Helms B, Dorval S, Laurent PS, Winter M (2010) Improving hand hygiene compliance: a multidisciplinary approach. J Infect Control 38: 572-574.

24. Erasmus V, Daha TJ, Brug H, Richardus JH, Behrendt MD, et al. (2010) Systematic review of studies on compliance with hand hygiene guidelines in hospital care. Infect Control Hosp Epidemiol 31: 283-294.
25. O'Boyle CA, Henly SJ, Larson E (2001) Understanding adherence to hand hygiene recommendations: the theory of planned behavior. Am J Infect Control 29: 352-360.

26. Novoa AM, Pi-Sunyer T, Sala M, Molins E, Castells X (2007) Evaluation of hand hygiene adherence in a tertiary hospital. Am J Infect Control 35: 676-683.

27. Reichardt C, KA-niger D, Bunte-SchA-nberger K, Linden P, MA-nch N, et al. (2013)Three years of national hand hygiene campaign in Germany: what are the key conclusions for clinical practice? J Hosp Infect 83: S11S16.

28. Picheansathian W (2004) A systematic review on the effectiveness of alcohol-based solutions for hand hygiene. Int J NursPract 10: 3-9.

29. Haas JP, Larson EL (2007) Measurement of compliance with hand hygiene. J Hosp Infect 66: 6-14.

30. Scheithauer S, Lemmen SW (2013) How can compliance with hand hygiene be improved in specialized areas of a university hospital? J Hosp Infect 83 Suppl 1: S17-22. 